\title{
International Tax Competition Complying with Laws: Who are its Beneficiaries?
}

\author{
Darina Saxunova, Daniela Novackova and Jana Kajanova \\ Faculty of Management, Comenius University in Bratislava, Slovakia \\ Odbojarov, Bratislava, Slovakia
}

Correspondence should be addressed to: Darina Saxunova; darina.saxunova@fm.uniba.sk

Received date: 7 March 2017; Accepted date: 28 July 2017; Published date: 28 February 2018

Academic Editor: Anca Costea-Dunărințu

Copyright (C 2018. Darina Saxunova, Daniela Novackova and Jana Kajanova . Distributed under Creative Commons CC-BY 4.0

\begin{abstract}
Globalisation has brought many positive and negative phenomena for the entrepreneurship, society and its citizens. One of them is taxation. Has this phenomenon caused positive or negative consequences for the taxpayers or the country's public finance? The answer is very complicated, which is obvious as the Common consolidated corporate tax base (CCCTB) has not been finalised yet, this ongoing problem was deferred for solving to the future. Professional and political voices for continuation in accomplishing this agenda are reviving, the process how to carry on has commenced again. In October 2016, the European Commission proposed to relaunch the СССТВ agenda. Economists share different opinions on coping with tax problems. The corporate taxpayers strive to minimize their tax liabilities as much as possible, or not to pay taxes at all. This situation results in the shortage of financial resources for the state budget. These resources are difficult to replace in public financing projects. But the EU guarantying free movement of goods and services, labour force and capital encourage indirectly or makes it even easier for corporations to transfer their profit into the states with lower or zero tax rates in order to avoid tax liability or reduce it. The objective of this scientific paper is to clarify existing tax competition trends and highlight forms of investment regional aid - tax relief or tax holidays offered by Slovak government; thereby tax stimuli provided by the state represent an official, legal instrument for enhancing the business' competitiveness. No doubts when do the investors evaluate and analyse business environment of their targeted investing destinations they must pay attention to the tax system of a particular state.
\end{abstract}

Keywords: tax rates, tax exemption, tax relief, tax competition

Cite this Article as: Darina Saxunova, Daniela Novackova and Jana Kajanova (2018)," International Tax Competition Complying with Laws: Who are its Beneficiaries? ", Journal of Eastern Europe Research in Business and Economics, Vol. 2018 (2018), Article ID 145385, DOI: 10.5171/2018.145385 


\section{Introduction}

Many politicians or economists are against tax harmonisation, they argue taxes and taxation should remain as an instrument of competitive advantage, especially if the country has low tax rates and the countries are in a big need of attracting FDIs. States that are interested in developing economic relations with foreign investors provide these investors with tax advantages and thereby manage to attract FDIs to the country. Foreign investors, as recipients of such advantage, can frequently improve their position in the market. Despite the existence of a variety of opinions and approaches towards taxation and tax reliefs or exemptions, all interested parties who can add the value to the debate on tax issues, have agreed and supported the European Commission's decision to re- launch СССТВ agenda. Tax income represents a substantial source of public finance in contemporary economies. Tax income contributes to the public finance budget, resources of which will be used for essential and inevitable public consumption. The appropriate level of the public expenditures is determined by historical and socio-economic characteristics of production and providing public products and services in a specific territory. Taxes mean irreclaimable compulsory payments, a levy imposed on taxpayers, as far as the size of cash flows is concerned, the amount is precisely determined by the tax legislation or levied by the state or regional municipal authority. Taxes are collected by these authorities at a certain maturity date and will be used for public goods and services payments. In theory of tax legislation, a tax is understood as a cash consideration levied by the law or it is required to be settled down by legal (corporations) or natural entities (soleproprietors or employees) for public expenditures. Taxes and a state tax system is the object of an ongoing interest of professional, scientific and laic community. Taxes and tax system's position and significance within economic and political environment forming macro-environment of entrepreneurial economic entities penetrate in numerous spheres: such as political stability, economic growth, quality of enterprising environment, purchase power of inhabitants, state budget, assurance of meeting state's fundamental functions and roles. (Kajanova, 2015).

\section{Objectives and Methodology}

The scientific paper focuses on the taxation, especially on the international tax competition and its significance for the public finance and enterprising environment in the state. The objective of this scientific paper is a) to identify existing trends in the area of tax competition and b) to clarify fundamental threshold and common systematic factors in order to determine whether an investment regional aid will be granted in the form of tax relief or tax holidays in Slovakia. Therefore, tax stimuli provided by the state represent a legal instrument for enhancing the economic entity's competitiveness whose efficiency and effectiveness may be studied by assessing the impact on foreign trade. Moreover, it also focuses on critical analysis of the impact of tax exemption on enterprise competitiveness. Tax rates development in the EU on corporate income serves as information for concluding whether tax revenue collection was affected by granting tax holidays to the investors. Practical experience of the perception of tax exemption by Slovak entrepreneurs was summoned and advantages and disadvantages were formulated for Slovak conditions. Slovak legislation must be applied to keep economic competition in conformity with the EU and Slovak legislation. Scientific methods of comparison, analysis and synthesis, deduction was applied. No doubt when is business environment analysed or evaluated, tax system of the state should not be ignored 


\section{International Taxation versus Foreign Direct Investment}

Tax policies of economic legal entities worldwide are in a state of flux, since the corporate income tax systems have undergone the reform because of continuous process of globalisation as proclaimed by the researcher Zodrow (2010). The reform has been taking place in an environment where a highly mobile international capital, international tax competition and aggressive international tax avoidance by many multinational companies are frequently present. Competing to obtain the capital through reducing tax rates on corporate income may be witnessed by many countries that lowered corporate tax rates owing to attracting foreign direct investments (FDIs) (see table 1) especially in less developed countries, on the other hand in developed countries the tax rates are lowered because of protecting established corporations from moving abroad. Other arguments for tax cuts were added by Johansson with the team of researchers based on the results of their OECD study (2010, p.24) concluding that "high corporate tax rates may reduce incentives to invest in innovative activities by reducing their after-tax return and to the extent that corporate taxes reduce FDI and the presence of the multinational companies they can hinder technology transfer and knowledge spillovers to domestic firms" (Johansson et.al, 2010). Altshuler (2010, p.66-71) studied US multinational corporations for the purpose of assisting to guide a corporate tax reform coming to significant conclusions: a) "US real capital is mobile and has become more sensitive to differences in host country tax rates, b) opportunities for cross-border income shifting are an important feature of both worldwide and territorial tax systems, c) governments are engaged in tax competition and it has likely intensified over time, and d) host country governments and multinational corporations are all players in the tax competition game." The period after the financial crisis is characteristic with problems of economic recovery of the countries, moreover, it is complicated by the political situation caused by war conflicts and tackling the problem of immigration. Therefore, even tax exemption as economic stimulus can be utilized in competing for FDIs, although the arguments emphasize that this is not a solution in the long run for the emerging and developing countries. Many countries in the EU decided to lower a tax rate on corporate income and broaden the taxable base to increase the amount of tax revenue collected.

\section{Tax Rates Development in the European Union}

The right to impose a levy on taxpayers and then to collect taxes belongs to the fundamental elements of the sovereignty of each EU member state. The EU member states have delegated only limited powers to the EU. Tax policy on the EU level is not focused on smooth functioning of single market. (Subertova, 2014).

The trend of the recent years is the proof of an increase in flat tax-rate utilization, especially in the countries of Central and Eastern Europe (see table 1), which ignited reforms of tax systems in the states with high tax rates. Bulgaria has the lowest tax rate $10 \%$ plunging to this level from $40 \%$ tax rate in 1995 and Ireland and Cyprus are also attracting investors with low tax rate of $12.5 \%$. 
Table 1: Tax Rates on Corporate Income (CI) in the EU member states below the EU average

\begin{tabular}{|l|c|c|c|c|c|c|}
\hline $\begin{array}{l}\text { State Rates } \\
\text { in percentage }\end{array}$ & $\begin{array}{c}\text { CI } \\
\mathbf{\%}\end{array}$ & $\begin{array}{c}\text { CI } \\
\mathbf{\%}\end{array}$ & $\begin{array}{c}\text { CI } \\
\mathbf{\%}\end{array}$ & $\begin{array}{c}\text { CI } \\
\mathbf{\%}\end{array}$ & $\begin{array}{c}\text { CI } \\
\mathbf{\%}\end{array}$ & $\begin{array}{c}\text { CI } \\
\mathbf{\%}\end{array}$ \\
\hline BG Bulgaria & $\mathbf{1 9 9 5}$ & $\mathbf{2 0 0 0}$ & $\mathbf{2 0 0 5}$ & $\mathbf{2 0 1 0}$ & $\mathbf{2 0 1 4}$ & $\mathbf{2 0 1 5}$ \\
\hline CZ Czech Republic & 40.0 & 32.5 & 15.0 & 10.0 & 10.0 & 10.0 \\
\hline EE Estonia & 26.0 & 41.0 & 26.0 & 19.0 & 19.0 & 19.0 \\
\hline IE Ireland & 40.0 & 24.0 & 24.0 & 21.0 & 21.0 & 20.0 \\
\hline HR Croatia & 25.0 & 35.0 & 20.0 & 20.0 & 20.0 & 20.0 \\
\hline CY Cyprus & 25.0 & 29.0 & 10.0 & 10.0 & 12.5 & 12.5 \\
\hline LV Latvia & 25.0 & 25.0 & 15.0 & 15.0 & 15.0 & 15.0 \\
\hline LT Lithuania & 29.0 & 24.0 & 15.0 & 15.0 & 15.0 & 15.0 \\
\hline HU Hungary & 19.6 & 19.6 & 17.5 & 20.6 & 20.6 & 20.6 \\
\hline PL Poland & 40.0 & 30.0 & 19.0 & 19.0 & 19.0 & 19.0 \\
\hline RO Romania & 38.0 & 25.0 & 16.0 & 16.0 & 16.0 & 16.0 \\
\hline SI Slovenia & 25.0 & 25.0 & 25.0 & 20.0 & 17.0 & 17.0 \\
\hline SK Slovakia & 40.0 & 29.0 & 19.0 & 19.0 & 22.0 & 22.0 \\
\hline FI Finland & 25.0 & 29.0 & 26.0 & 26.0 & 20.0 & 20.0 \\
\hline SE Sweden & 28.0 & 28.0 & 28.0 & 26.3 & 22.0 & 22.0 \\
\hline $\begin{array}{l}\text { UK United } \\
\text { Kingdom }\end{array}$ & 33.0 & 30.0 & 30.0 & 28.0 & 21.0 & 20.0 \\
\hline EU average & $\mathbf{3 5 . 0}$ & $\mathbf{3 2 . 0}$ & $\mathbf{2 5 . 3}$ & $\mathbf{2 3 . 2}$ & $\mathbf{2 2 . 9}$ & $\mathbf{2 2 . 8}$ \\
\hline EA average & 35.8 & 33.3 & 26.7 & 24.5 & 24.8 & 24.6 \\
\hline
\end{tabular}

Source: processed by author using (OECD, 2016, 2015)

Countries with high tax rates such as countries of the Northern Europe -Sweden and Finland have reduced their tax rates as most of the countries in Central and Eastern Europe, similarly the United Kingdom, already exiting member state of the EU. High rates for taxation of capital gains in the states may result in transferring the wealth abroad, into the states with lower tax rates. Lower tax rates enable broadening an income tax base. A tax model of the flat rate represents the linear variant of complex income tax; it usually is included to the tax base for several or all capital gains. The following table demonstrates the development of the percentage of tax rates on corporate income in the EU states with higher than EU average value. Many of the countries lowered their tax rates not so radically low as the previous group of states in Table 1 , but the unique example is France as the only country in the EU that increased its tax rate on corporate income to $38 \%$. Malta has not changed its rate- stable $35 \%$ and almost stable rate may be seen over years in Norway $-28 \%$, just in 2015 it declined by $1 \%$. We included EU member states into the table 1 or 2 based on the value of corporate tax rates in the year 2015. 
Table 2: Tax Rates on Corporate Income (CI) in the EU member states over the EU average

\begin{tabular}{|l|c|c|c|c|c|c|}
\hline $\begin{array}{l}\text { State Tax Rates } \\
\text { in percentage }\end{array}$ & $\begin{array}{l}\text { CI } \\
\mathbf{\%}\end{array}$ & $\begin{array}{c}\text { CI } \\
\mathbf{\%}\end{array}$ & $\begin{array}{c}\text { CI } \\
\mathbf{\%}\end{array}$ & $\begin{array}{c}\text { CI } \\
\mathbf{\%}\end{array}$ & $\begin{array}{c}\text { CI } \\
\mathbf{\%}\end{array}$ & $\begin{array}{c}\text { CI } \\
\mathbf{\%}\end{array}$ \\
\hline BE Belgium & $\mathbf{1 9 9 5}$ & $\mathbf{2 0 0 0}$ & $\mathbf{2 0 0 5}$ & $\mathbf{2 0 1 0}$ & $\mathbf{2 0 1 4}$ & $\mathbf{2 0 1 5}$ \\
\hline DK Denmark & 40.2 & 40.2 & 34.0 & 34.0 & 34.0 & 34.0 \\
\hline DE Germany & 34.0 & 32.0 & 28.8 & 25.0 & 24.5 & 23.5 \\
\hline EL Greece & 56.8 & 51.6 & 38.7 & 30.2 & 30.2 & 30.2 \\
\hline ES Spain & 40.0 & 40.0 & 32.0 & 24.0 & 26.0 & 29.0 \\
\hline FR France & 35.0 & 35.0 & 35.0 & 30.0 & 30.0 & 28.0 \\
\hline IT Italy & 36.7 & 37.8 & 35.0 & 34.4 & 38.0 & 38.0 \\
\hline LU Luxemburg & 52.2 & 41.3 & 37.3 & 31.4 & 31.4 & 31.4 \\
\hline MT Malta & 40.9 & 37.5 & 30.4 & 28.6 & 29.2 & 29.2 \\
\hline NL Netherlands & 35.0 & 35.0 & 35.0 & 35.0 & 35.0 & 35.0 \\
\hline AT Austria & 34.0 & 35.0 & 31.5 & 25.5 & 25.0 & 25.0 \\
\hline PT Portugal & 39.6 & 35.2 & 25.0 & 25.0 & 25.0 & 25.0 \\
\hline EU average & 35.0 & 32.0 & 25.3 & 29.0 & 31.5 & 29.5 \\
\hline EA average & 35.8 & 33.3 & 26.7 & 24.5 & 24.8 & 24.6 \\
\hline NO Norway & 28.0 & 28.0 & 28.0 & 28.0 & 28.0 & 27.0 \\
\hline
\end{tabular}

Source: processed by author using (OECD, 2016, 2015)

\section{Tax System and Slovak Legislation}

Taxes represent cash inflows of taxpayers to the state budgets. The income of the individuals and legal entities is subject to tax, so is their property or capital gains. The legal business entities which are headquartered in the Slovak Republic tax the income from the resources in Slovakia and the income from the resources abroad, regardless whether the legal entity has a firm business component abroad or does not. There are taxpayers headquartered abroad committed to establish an affiliate, subsidiary (a firm business component) in Slovakia, the income of these foreign legal entities generating by the Slovak affiliate or subsidiary (on the Slovak territory) is subject to tax. Equally, income from foreign resources which may be assigned to the firm business component in Slovak territory is also subject to tax in Slovakia. Taxpayers that are headquartered abroad and not having a duty to establish a firm business component in Slovakia, their income is subject to tax in Slovakia, namely only this part of their income generated by the resources on the Slovak territory. In
Slovakia investment project implementation is supported by the government, the institute of exemption from taxation is also utilised as an instrument of support to accomplish certain goals. The law N. 595/2003 Coll. on income tax defines the situations where tax exemption may be applied. Scientific study investigates the system of exemption from taxation and encourages the institute of tax fairness.

In general, Slovak tax system is assessed as relatively stable, with recent decline in flat corporate income tax rate $21 \%$ since 1.1.2017 for the legal entities and 20\% VAT for most of goods and services $110 \%$ for selected grocery item of Slovak production, medicaments and books) can compete with other states of Central and Eastern Europe. Slovakia introduced tax licence (prepaid minimum tax) to be paid by each legal entity which increased tax revenue and assisted in cleaning the market from the nonfunctioning companies, many of them were used for tax fraud (carrousel schemes) (Olvecka, 2016), but corporations are strongly against. There is a promise of the 
Slovak political party to abolish this tax licence in spite of its positive benefits for the state budget and also economic entities' tax behaviour.

\section{Providing Tax Investment Stimuli As An Instrument For Strengthening Competitiveness In Slovakia}

Gravelle (2010, p.38) states that the history of the explicit investment subsides can be dated back to sixtieths with introducing an investment tax credit, followed by the adoption of another economic stimulus, such as an accelerated method for depreciation in 1954. Many countries experimented tax incentive for investment e.g. Sweden, the Netherlands, France, Italy, Germany, the United Kingdom, Canada and Japan, but their use led to dissatisfaction, because they used to cause distortions and inequities. Gravelles (2008) considers investment credit to be almost as costly per dollar as a tax rate reduction. Based on the findings in a small open economy it might be more detrimental for the state budget or a welfare to grant tax rate reductions or investment aid, on the contrary little gain can be expected in the long- run welfare.

The contemporary process of globalisation enables to evaluate competitiveness and quality of entrepreneurial environment through several assessing indices. Investment stimuli provided by the states are considered the most significant competitive advantages. The existing legal framework regulating the investment stimuli affords providing investment aid in the following areas: in manufacturing, technological centres, centres for strategic services and in the tourism.

Prerequisites for providing investment aid are unwound from the project alignment and from the unemployment in a particular region, whereas projects with the larger extent of an added value and sophisticated production are subsidised with a larger financial assistance. Investors must finance minimum of $25 \%$ of licit expenses from other resources, thus, e.g. by taking a bank loan or from shareholders' resources.

Economic entities may obtain the following forms of the investment stimuli:

- subsidies for acquiring tangible and intangible assets (the volume of the subsidy depends on the state budget resources,

- income tax reliefs complying with the specific regulation,

- contribution for newly created working positions complying with the specific regulation.

To conclude, the exemption from taxation belongs to the structure of investment stimuli. It is considered as the economic instrument of enhancing competitiveness. The investment stimulus recipient obtains an advantage improving its market position. The recipient is enabled to invest their own resources into the latest state-of-the-art technologies which may result in ensuring economic progress in the future since tax stimuli are time limited. An advantage is economic benefits. Whenever the financial situation of an economics entity is improved because of State intervention, an advantage is present. To assess this, the financial situation of the economic entity following the measure should be compared with its financial situation if the measure had not been introduced (Case 173/73, Italy v Commission [1974] ECR 709, paragraph 13)

\section{Discussion and Results}

The following table summarizes information on the total tax credits remunerated to the corporations granted this tax relief instrument as a compensation for investing in Slovakia and creating working position in Slovakia. In the last column, FDIs inflows are shown not confirming entirely the argument that when the tax credit is provided it will attract the FDIs flowing to the country. Because tax credit is stipulated by the condition, that investment must go to the regions with very high unemployment and 
with low generated GDP, investors may prefer more developed region promising higher profits sacrifying certain economic stimuli.

Table 3: The volume of the investment aid provided as the income tax relief

\begin{tabular}{|c|c|r|r|c|r|}
\hline Period & \multicolumn{2}{|c|}{$\begin{array}{c}\text { Number of investment } \\
\text { stimuli recipients }\end{array}$} & \multirow{2}{*}{$\begin{array}{c}\text { Investment aid } \\
\text { provided in Eur }\end{array}$} & $\begin{array}{c}\text { Ranking } \\
\text { in }\end{array}$ & $\begin{array}{c}\text { FDIs } \\
\text { inflows }\end{array}$ \\
& $\begin{array}{c}\text { Foreign } \\
\text { companies }\end{array}$ & $\begin{array}{c}\text { Slovak } \\
\text { companies }\end{array}$ & As tax credits & $\begin{array}{c}\text { Tax } \\
\text { credit/FDI } \\
\text { s }\end{array}$ & $\begin{array}{c}\text { USD } \\
\text { millions }\end{array}$ \\
\hline $\mathbf{2 0 0 6}$ & 39 & 0 & $€ 206,950,024$ & $1 . / 1$. & 5806 \\
\hline $\mathbf{2 0 0 7}$ & 15 & 0 & $83,008,867$ & $4 . / 3$. & 4018 \\
\hline $\mathbf{2 0 0 8}$ & 6 & 1 & $34,697,514$ & $6 . / 2$. & 4858 \\
\hline $\mathbf{2 0 0 9}$ & 7 & 2 & $30,512,767$ & & -7 \\
\hline $\mathbf{2 0 1 0}$ & 7 & 0 & $10,222,807$ & lowest & 1770 \\
\hline $\mathbf{2 0 1 1}$ & 10 & 1 & $33,093,017$ & & 2146 \\
\hline $\mathbf{2 0 1 2}$ & 10 & 1 & $121,191,498$ & $2 . / 3$. & 2826 \\
\hline $\mathbf{2 0 1 3}$ & 10 & 1 & $48,346,268$ & 5. & -604 \\
\hline $\mathbf{2 0 1 4}$ & 8 & 2 & $88,364,651$ & 3. & -332 \\
\hline $\mathbf{2 0 1 5}$ & 10 & 3 & $25,674,521$ & & 803 \\
\hline $\mathbf{2 0 1 6}$ & 3 & 2 & $21,212,000$ & Q1, Q2 & $487 * /-994$ \\
\hline $\mathbf{2 0 1 7}$ & 7 & 1 & $12,591,425$ & $1^{\text {st }}$ month & \\
\hline
\end{tabular}

Source: Adapted from (Ministry of Economy, SR, 2016) and (OECD, 2016, 2017)

Slovak government approved investment aid in the form of the exemption from taxation for the legal entities' income. This form of subsidy is non-cash form of stimuli, because it does not require cash movement, only the government forgoes tax revenues from the income of subsidised legal entities. Waiving revenue which would otherwise have been paid to the State constitutes a transfer of State resources (Case C-83/98 P France $v$ Ladbroke Racing Ltd and Commission [2000] ECR I-3271, paragraphs 48-51) leading to a deficit in the system of social allowances due to the tax revenues forgone.

In Slovakia the recipients of such advantage are especially foreign enterprise companies operating in the regions with a high rate of unemployment. The balance between the economic competition and advantages flowing to Slovakia from these investments is ensured and therefore it may be stated that the provided investment aid into regions is legal, emphasizing that a legal entity has no legal claim on it. Investing stimuli are provided complying to the article 107.3 (a) of the Treaty on the EU Functioning, referencing to it the assistance may be considered compatible with the internal market, if supporting economic growth of the areas where standards of living is exceptionally low or there is exceptionally high unemployment.

The following figure demonstrates that despite the tax credits provided to the foreign corporations (most recipients are foreign entities), Slovakia collected tax revenues slightly below the OECD average till 2008 but in a steadily growing pace, the growth was interrupted by the period of financial hardship, in which the overall global economy, not only the Slovak one, slowed down and since 2012, the amount of tax collection is steadily growing overtaking 
even OECD average tax collection, presented in figure 1.

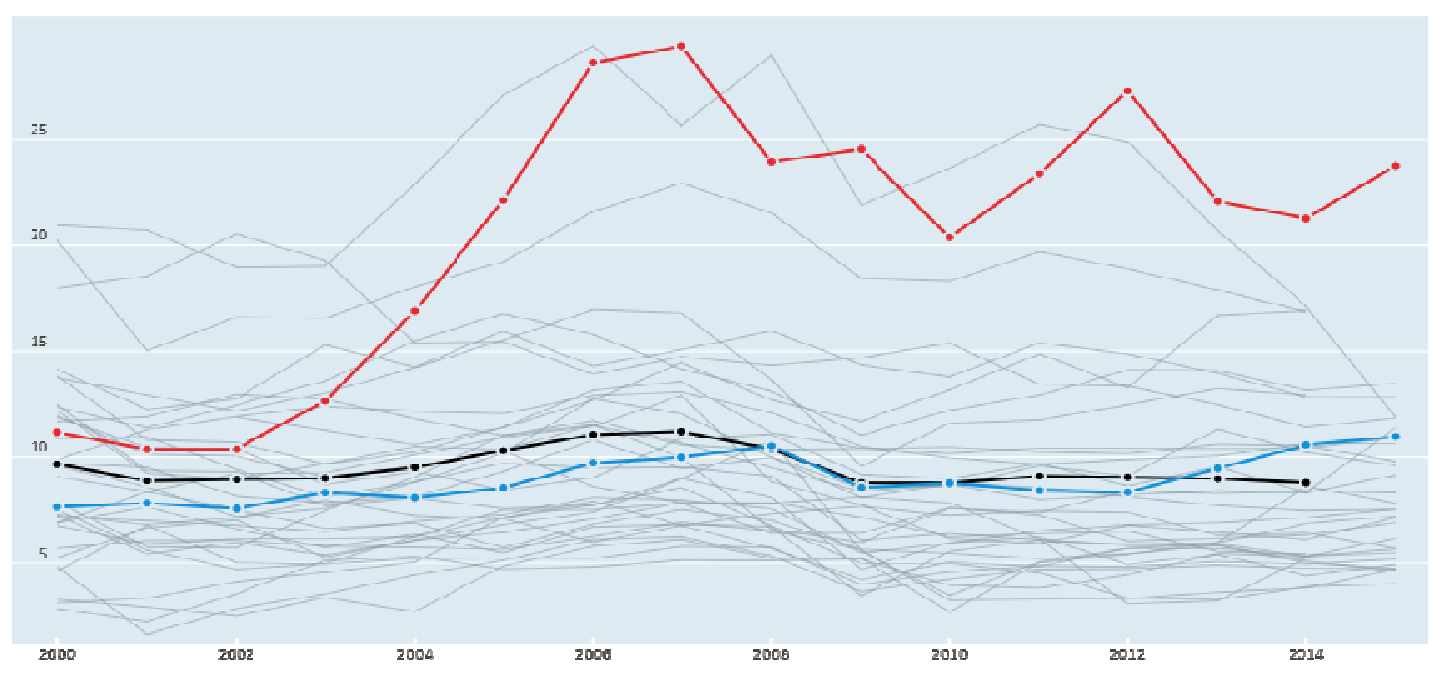

Fig.1: Taxes on corporate income as a percentage of taxation

Legend: red line (top) Chile; blue line: Slovakia, black line: OECD

Source: (OECD, 2016)

Slovakia's collection of corporate taxes as a percentage of taxation is demonstrated in blue line, in Slovakia since 2013 taxes collected are higher than tax collection in OECD, represented by OECD countries' average tax amount which is illustrated with the black line in Figure 1. The highest taxes that have been collected since 2012 are in Chile and in Norway, (the period around 2001-2003, it was Luxembourg).

Table 4: Corporate Taxes as a 1) percentage of taxation/2) percentage of GDP in Slovakia in 2006-2015.

\begin{tabular}{|l|l|l|l|l|l|l|l|l|l|l|}
\hline In \% & $\mathbf{2 0 0 6}$ & $\mathbf{2 0 0 7}$ & $\mathbf{2 0 0 8}$ & $\mathbf{2 0 0 9}$ & $\mathbf{2 0 1 0}$ & $\mathbf{2 0 1 1}$ & $\mathbf{2 0 1 2}$ & $\mathbf{2 0 1 3}$ & $\mathbf{2 0 1 4}$ & $\mathbf{2 0 1 5}$ \\
\hline SK$^{*}$ & 9.73 & 9.99 & 10.53 & 8.56 & 8.77 & 8.43 & 8.35 & 9.47 & 10.58 & 10.96 \\
\hline SK** & 2.85 & 2.92 & 3.06 & 2.47 & 2.46 & 2.41 & 2.37 & 2.87 & 3.31 & 3.54 \\
\hline
\end{tabular}

Legend: Corporate Taxes as a * percentage of taxation, **percentage of GDP in Slovakia in the period of 20062015

Source: (OECD, 2017)

Economic globalization assists to develop international investment relations and encourages economic growth and getting the national economies closer. Global inflows of FDIs have declined since 2008. The position of foreign mergers and acquisitions has weakened and therefore investment into equity has decreased. Slovak Republic, so as other countries of Central and Eastern
Europe strive to attract foreign investors, seeking regions with the lowest investment risks, the most frequently with the offer of tax holiday for them. See Annex for the illustration of the FDIs' trend in 2006-2015.

We may state referring to the global competitiveness index values of the World Economic Forum, from the 2016-17 report 
and the reports published from the years since 2012-13, that Slovakia's index is improving (see table 5). Since 2012- 2013 we have achieved the best value 65 out of 138 total countries measured, indirect influence of economic stimuli may be reflected into the value of this index, but there is still room for competitiveness improvement. Switzerland is the country which has achieved 1 . position in the ranking since 2009-10, the most recent score 5.81 is the historic best ever score so far for Switzerland, (Swiss values are from 5.67-5.81 in that focused period of the years 2012-13).

Table 5: Global competitiveness index: Slovakia compared to countries measured

in 2012-2017

\begin{tabular}{|l|c|c|c|c|c|}
\hline EDITION & $\mathbf{2 0 1 2 - 1 3}$ & $\mathbf{2 0 1 3 - 1 4}$ & $\mathbf{2 0 1 4 - 1 6}$ & $\mathbf{2 0 1 5 - 1 6}$ & $\mathbf{2 0 1 6 - 1 7}$ \\
\hline RANK & $\mathbf{7 1 / 1 4 4}$ & $\mathbf{7 8 / 1 4 8}$ & $\mathbf{7 5 / 1 4 4}$ & $\mathbf{6 7} / 140$ & $\mathbf{6 5} / 138$ \\
\hline SCORE & 4.1 & 4.1 & 4.1 & 4.2 & 4.3 \\
\hline
\end{tabular}

Source: Adapted from (WEF, 2017)

Slovakia is supporting competitiveness also through the amendment of the tax legislation since 2015. A new tax regulation enables to consider $25 \%$ of the total expenditure into research and development as tax deductible items, also it allows to deduct $25 \%$ of $R \& D$ expenditures from the previous year of the project which could not have been deducted in the previous year, i.e. they were not included due to the excess of the $25 \%$ amount allowed, and also researcher or innovator salary $(25 \%)$ is allowed to lower the taxable base if the researcher is younger than 26 years old and he is from the EU (two years from the graduation in daily program of studying), i.e. his salary expenses and other compensation can be deducted from the calculation of the taxable base for the research project. It encourages innovative activities that increase competitiveness and this tax relief is a motivating instrument for the Slovak entrepreneurs in order that they may get involved into the research and innovation process activities in their business.

\section{Tax Exemption Stimulus Provided on the Base of the Multilateral International Treaty}

Apart from the Act on investment stimuli in Slovakia, the investment aid, moreover, was provided to the enterprise in the form of exemption of the tax from the economic entity's income applying the multilateral international treaty. Slovakia became the EU member state in 2004 accomplishing the treaty on Accession to the European Union, where it is explicitly stated "investment aid provided in accordance with the Act $n$. 366/199 Coll. on Income tax mustn't exceed 500 million USD ". It means that the enterprising entity was exempted from taxation during the business performance up to 500 million USD, applying international multilateral treaty, what could be reflected in its research and development (OJ EU L 236.23.9.2003). To provide economic advantages to business entities when they access an international community is not an international custom.

\section{Negative aspects of investment stimuli assisstance - taxes}

At present there are several reasons highlighting also the negative consequences of the state aid through investment stimuli. In spite of complicated justification and quantification, it is not easy to determine the critical point when, where and how the costs will overflow, referring to benefits that were 
exceeding costs though. It creates a dilemma which investor will receive investment stimuli and in what volume. Despite the strict legal framework (Treaty on Functioning of the EU, the Act on investment stimuli), it is perplexed at the time of decision making to figure out the value of externalities, what is priority, because the positive effect in association with the national economic significance will be visible only under condition that investment stimulus will be lower than the value of the externalities. Another problem there is a risk of competition among the states; they eventually became rivals pursuing foreign investments. Not all the time each investment has to bring economic benefits for the host state and positive consequence on the GDP growth.

An investor must follow the golden rule of investing and pursue three fundamental criteria: yield, security and the degree of liquidity, despite stimuli the fulfilment of investors' expectations varies. There may be certain common features visible in Slovakia (offering tax holiday to attract FDIs) and countries in the tax paradise, for instance Belize, Hong Kong, Seychelles, Bahama
Islands, Monaco, Andorra etc. Countries of the tax paradise are characteristic by strong reduction or non-existence of corporate or personal income taxes and at the same time by the possibility of their repatriation abroad, by foreign exchange deregulation, by existence of relatively liberal licence policy, by lack of compulsory minimal reserve, by absenting rules for liquidity bank management or capital adequacy, by limited regulation of collective investment, by existence of very strict banking confidentiality, by political stability, by excellent information, telecommunication infrastructure or other advantages. Finally, the next paragraph is to summarize positive and negative aspects of state aid concluded from the experience gained from its recipients or its providers in Slovakia.

The positive aspects of state aid cover: regional development, creating working positions, increase of the standard of living, innovation of the companies, pro-export advantage for Slovakia, product diversification, knowledge and know-how, support to SMEs, training aid, and the effort for business sustainability (Figure 2).

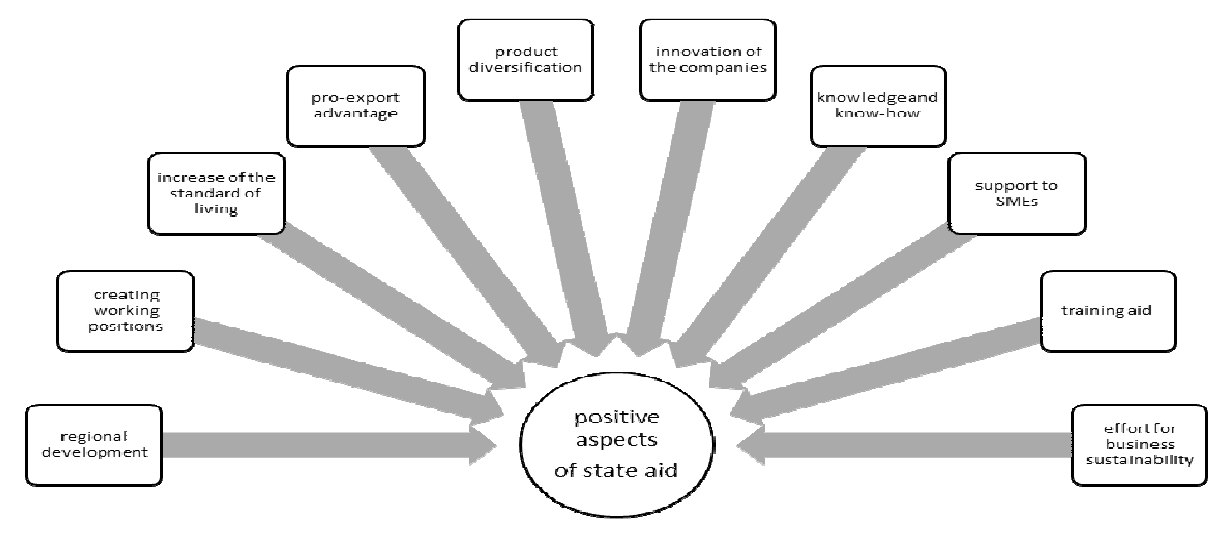

Source: own elaboration

Fig. 2: Positive aspects of state aid

Development of Slovak regions is different. The aim is to bring or settle their conditions and functionality. The disparities in the regions can be identified through monitoring employment, regional average wages, accessing to social security or 
employment opportunities, costs of housing, and conditions for doing business. The regions in Slovakia differ also in the municipal property tax rates that may be utilized in the context of attracting investors to unfavored regions.

New jobs positions are a prerequisite for the state aid, as the main objective of the current policy is to reduce unemployment. Given the positive results were achieved in the real unemployment, support should be moved to regions where the unemployment rate is still high compared with the average unemployment in Slovakia. Unfortunately, however, Mayer et al. (2011) found out that the supported problematic areas by various state programs tend to attract smaller firms, and not the larger ones. Isolated regions are not attractive for the big businesses and the distance makes the programme less efficient. Tax differentials between regions is the one of main determinants influencing the location choice for business, despite a significant impact on location choices, the magnitude of their impact on firms' location choices or employment created is small. (Combes \& Ypersele, 2013). Thus, various tax holidays (state aid form) offered investors from abroad in the case of capital shortage is a necessity.

The part of state aid is also directed to entrepreneurial environment. Supporting micro, small and medium-sized enterprises is a way to influence the unemployment, to promote new jobs, to help problematic regions. Maintaining of entrepreneurial activity helps to secure long-term positions, to use state aid to ensure the sustainable development of enterprises, which have used these sources. Disparities in the regions result in differences of living standards of the population. The current problem is the widening of the differences as follows: the quantity of the middle class is decreasing and the share of regions with higher and lower living standards is increasing. The problematic section is mainly the increase of socially disadvantaged regions living on the poverty line. The one of solutions could be the different rates for social allowances to make an ease starting to develop such regions especially for sole-proprietorship (in Slovakia the rate is $48.6 \%$ of the income). In addition, state aid could be provided also to micro, small and middle businesses, the benefits should not be judged by the monetary returns, also by a non-monetary return or some other tax relieving instruments intended to help economic sustainability.

Granting of state aid is also linked to innovation. Continuous development of information and communication technologies, technical and technological development, or nanotechnologies set new demands on enterprises in Slovakia. Ensuring and maintaining competitiveness is the result of an open economy, pro-export policy and efforts to expand products of Slovak enterprises on global markets. Another option is product diversification. The consumer or the customer is becoming more demanding. Looking for new products or services increases pressure on the competitiveness of Slovak enterprises. On the other hand, the new portfolio, results of innovations, can be introduced on foreign markets. This could be solution for not enhancing tax competitiveness with lowering corporate tax rates.

The utilization of state aid has a direct impact on the development of knowledge and know-how, as well. Different trainings and education processes enable to involve a lot of unemployed people to the work process, especially those, who are not successful in the labour market without changing their education. Moreover, training and education should be focused also on the area of tax avoidance, fraudulent tax schemes, which steal financial resources from the state budget. Educated and experienced, and first of all, highly ethical public representatives in the services of EU member states or in the OECD or non-OECD level are very valuable and needed for the preparation high quality legislation which would bring fair and just taxation laws. 
The negative aspects (Figure 3) of state aid are as follows: decrease in competitiveness, state budget resource decline, tension between recipients and non-recipients, nonethical practices to be granted the state aid, negative impact on non-recipients, they seek the way of avoiding to pay taxes -tax avoidance, or tax fraud, less resources from the state budget for the public sphere, uninterest or unwillingness to go to the disadvantaged regions, and difficulties of judging whether a state aid is not only interfering (public interest cases).

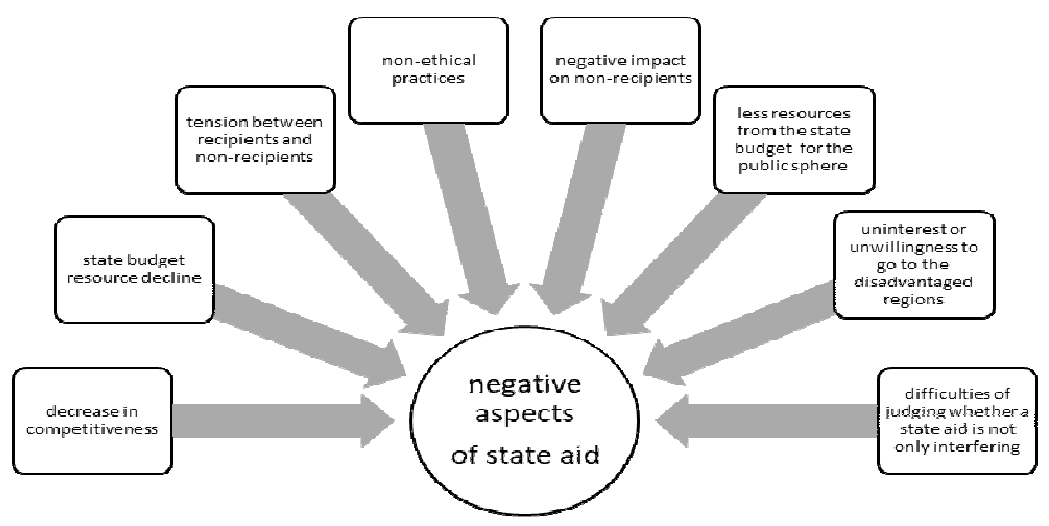

Source: own elaboration

Fig.3: Negative aspects of state aid

The advantage of enterprises granted with state aid automatically discriminates other companies such assistance did not receive. The use of state aid has a direct impact on the capabilities and activities of enterprises, on their achievements. But the state aid also may be implemented through the favorable and enterprise supporting legislation. For example, to support obtaining capital by a corporation in the USA, a company which needs capital when it issues preferred stock this investment is supported by tax legislation because investing into $100 \%$ package of this preferred stock issuance, the investor's preferred stock dividends are exempted from taxation.

Providing of state aid increases the expenditure part of the state budget. It reduces the resources which could be intended for reallocation to other sectors. Resources used as State aid reduce the amount of funds which could be used in the public administration.
The disadvantage of enterprises, which could not benefit from state aid, puts pressure on enterprises which take the part of the same markets and competitive environment. They must cope with the current situation and changes without support from the state budget. The feeling of injustice and different conditions within the same environment has a discouraging effect. In some cases, it is possible to talk about devastating conditions.

By favouring certain enterprises always creates tensions between entities operating in the same environment, but with different state support. The problem is the state aid is often not only used as a tool to help disadvantaged regions. At the same time, there is a discussion about the use of State aid in the public interest.

The evaluation goal of providing investment stimuli is to judge positive and negative consequences on the state economy. Nowadays, new working position, sustainability of created working position 
and the growth of GDP in a particular region are specific indicators for goal evaluation for a recipient of the investment stimulus which enterprises and operates its business entity in this region.

Evaluation of the efficiency and effectiveness can be judged also by assessing the impact on foreign trade. Exporting performance of the economy (measured by the ratio of the products and services export to GDP) has declined by $1.1 \%$ to $91.9 \%$ level. Import to GDP indicator (measured by the ratio of the products and services import to GDP) was reduced by $0.6 \%$ to the level of $87.8 \%$. Slovak economy openness (measured by the ratio of the foreign trade turnover to GDP) achieved the level of $179.7 \%$ in 2014 which was a decline by $1.7 \%$.

The recipients of the investment stimuli are operating in the automobile industry and electro-technical engineering industry. The most exporting commodities from Slovakia are automobiles representing a $25 \%$ share of the total volume of the foreign trade. Exported electric machines, instruments and equipment contribute to the total volume of foreign trade by $20.9 \%$ share. (Ministry of Economy,SR 2015)

A universal sign of the tax system is tax fairness/equity which should be in balance with economic efficiency. According to Escoffier and Fortin (2006), and Saxunova, Malach, \& Heindrichs (2016) a high standard tax system is:

1) economically effective

2) just and fair,

3) simple tax administration

4) flexible - tax system should react promptly and flexibly to the changes in the economy.

5) politically transparent tax system - it is easy to understand how much and where tax-payers pay a compulsory contribution to state revenue, legislative tax amendments are transparent.

The negative effects of the tax system on welfare and economic efficiency should be minimized, administration and compliance costs of the tax system should follow the idea that a system that costs less to operate is preferable, fairness also in other sense than in the distributional sense - fairness of procedures, avoidance of discrimination, and fairness with respect to legitimate expectations. Finally, transparency - a tax system that people can understand is preferable to one that taxes by "stealth". Simple, neutral and stable tax systems are more likely to achieve these outcomes than are complex, non-neutral and frequently changing systems. But simplicity, neutrality and stability are desirable because they promote these ultimate outcomes, nit in their own right. (Mirelees, 2011). The concept of optimal taxation, that is getting taxation right, is concerned with economic efficiency and equity/ fairness (Jane Frecknall-Hughes, 2016).

Optimal tax system means to seek and create compromise i.e. trade-off between the concept of economic efficiency and equity/ fairness. A competitor obtaining tax stimuli improves its market position but his rivals not being subsidized, operating without tax stimuli many times are not capable of resisting strong competition pressure and their market position is weakened or lost. Contemporary decisions of the government of Slovak republic related to the tax stimuli, from the perspective of analysing tax legal system may be questioning equity and fairness of Slovak tax system and also its economic efficiency.

Tax authorities conduct controls of the investment aid recorded in the recipients' accounting documentation (Ledger and reports). There have been no shortcomings found out when controls were performed concerning the use of state aid resources, eligibility of expenses incurred and complying to the terms of provided state aid. Slovak Republic has one dispute concerning the state aid provided to the company Frucona, Inc. Košice, but this dispute was finalized in 2016. (Frucona Košice a.s. Case T-11/07, State aid C 25/05, Case C-73/11 P, 
Case T-103/14) (Annuls Commission Decision 2014/342/EU of 16 October 2013 on State aid No SA.18211 (C 25/2005) (ex NN 21/2005) granted by the Slovak Republic for Frucona Košice a.s. (European Commision, 2017)

\section{Conclusion}

Attractiveness of business environment is characterised by several factors, significant position belongs to the tax credit investment stimuli. They are considered to be economic instruments lowering risk of unsuccessful implementation of investment projects and assisting in accomplishing investor's project expectations. Each investor expects profitability and sufficient return form the investment. To conclude, we may state that investing stimuli can be understood as the instruments of enhancing competitiveness.

Market economy is linked with a great deal of changes, variances, taking place in the global environment in which an entrepreneur has to react and adjust, or to foresee and analyse them, select alternatives or think over them and at the same time it brings numerous uncertainties and risks. Certain level of risks is accepted since future cash flows are uncertain. Risk is a degree of uncertainty of the financial environment linked to the yield, risk and return trade off, which has made an investor make a decision evaluating all pros and cons of bringing FDIs into unknown and risky terrain. According to Wamboye \& Mookerjee (2014), one of the positive aspects of globalisation is that state foreign direct investments may be the driver of financial sector development". Tax legislation may support public finance, from which all taxpayers may benefit, if tax collection policy is implemented fairly and justly. If the tax stimuli are distributed in a way that it encourages entrepreneurs to become more competitive in the market it results in a stronger economy. Their increasing profitability should lead to more satisfied employees earning more, their purchasing power grows, and state budget should be filled by higher corporate tax collection and by indirect taxes collected from increased sales due to the stronger consumers' purchase power. Their satisfaction will be enhanced also due to the realization of projects for the general public financed by the state contribution or from the resources from the state budget. Of course, high moral of entrepreneurs, alike also government and parliament members or representatives of public authorities at home, or in the international level and their greediness may be a big obstacle to it.

Therefore, tax legislation of the state should be a high quality legislation not allowing tax avoidance, tax evasion, or tax fraud. This is a real challenge for all responsible authorities. Moreover, it is also an immense challenge for achieving highly ethical behaviour of all participants and creators contributing to the creation of fair tax system, not only in the national level but also in the multinational level. Then we will be able to conclude that the whole society will benefit.

\section{References}

1. Altshuler R., (2010), 'Lesson from the study of taxes and the behavior of US multinational corporations', 61-78. In: CLaus I. - Gemmel N. - Harding M. - White D. Tax Reform in Open Economies. Cheltenham, UK.

2. Combes, P., \& Ypersele, T. (2013). 'The role and effectiveness of regional investment aid: The point of view of the academic literature' (1 ${ }^{\text {st }}$ ed., p. 138). Luxembourg: EUR$O P$.

3. Dennis-Escoffier, S., - Fortin, K.A., (2006, 'Taxation for Decision Makers', Upper Saddle River, Pearson.Prentice Hall, 33-54.

4. Frecknall-Hughes, J., (2015), 'The Theory, Principles and Management of Taxation', Routledge, Francis Taylor Group, NY.

5. Frucona Košice a.s., v. European Commission Case T-103/14, [Online], [Retrieved December 22, 2016], http://curia.europa.eu/juris/document/doc ument.jsf;jsessionid=9ea7d0f130d61af49b46 
c2774573a7cae361c961bcc2.e34KaxiLc3eQc 40LaxqMbN4PahmRe0?text=\&docid $=175134$ \&pageIndex $=0 \&$ doclang $=E N \&$ mode $=$ lst\&dir $=$ $\underline{\text { \&occ }=\text { first } \& \text { part }=1 \& \mathrm{cid}=186659}$

6. Gravelle, J., (2010), 'Economic Effects on investment subsidies', 38-61, In: CLaus I. Gemmel N. - Harding M. - White D., 'Tax Reform in Open Economies'. Cheltenham, UK.

7. Johansson, A., Heady Ch., Arnold J., Brys B., Vartia L., (2010), 'Taxes and firm performance: evidence from the OECD', 15-37, In: CLaus I. - Gemmel N. - Harding M. - White D. 'Tax Reform in Open Economies'. Cheltenham, UK.

8. Kajanová, J., (2015), 'Vývoj priamych daní na Slovensku', Maneko, 2015,VII (1), 17-26.

9. Mayer, T., Mayneris, F. and Py, L. (2011). The impact of urban enterprise zones on establishment location decisions - evidence from French ZFUs. Processed, Sciences Po Paris.

10. Novackova, D. Saxunova, D., Paskrtova L. (in press), Investment Aid as a Catholicon for Regional Development in Slovakia? International Journal of Economic Policy in Emerging Economies, Inderscience

11.OECD. Data, (2016), . [Online], [Retrieved December 22, 2016], http://www.oecd.org/

12.OECD, (2016), ' Gross domestic product (GDP) (INDICATOR)', DOI: 10.1787/dc2f7aec-en [Online], [Retrieved December 22, 2016], http://www.oecd.org/

13.0ECD. Data, (2017), [Online], [Retrieved February 20, 2017], http://www.oecd.org/

14.Ölvecká, V. (2016). The analysis of tax licence consequences on global business environment. Globalization and Its SocioEconomic Consequences: International Scientific Conference Žilina : University of Žilina, 2016 (vol 4), 1604-1612. . [Online], [Retrieved March 1, 2017, http://ke.uniza.sk/sites/default/files/conten t files/proceedings part iv.pdf

15.The Treaty of Accession 2003 of the Czech Republic, Estonia, Cyprus, Latvia, Lithuania, Hungary, Malta, Poland, Slovenia and Slovakia. Signed in Athens on 16 April, 2003. (OJ EU L 236.23.9.2003)

16.Saxunová D., Malach,P, Heinrichs J., (2016),'Fair taxation as a regional development driver', ABEM Conference Proceedings 2016, Winnipeg, Canada, Academy of Business and Emerging Markets. p.4.

17.Šúbertová, E.,(2014), 'Podnikatel'ské prostredie vEurópskej únii’, Bratislava, Kartprint, 1- 128.

18.Wamboye, E. \& Mookerjee, R., (2014), 'Financial development and manufactured exports: the African experience', International Journal of Economic Policy in Emerging Economies, 2014. Vol.7(1), 22 - 34.

19.World Economic Forum, (2017), Global Competitiveness Report "2016-2017", (PDF), [Online], [Retrieved March 1, 2017], http://www3.weforum.org/

20.Zodrow, G.K.,. (2010), 'International Taxation and company tax policy in small open economies',109-133. In: CLaus I. Gemmel N. - Harding M. - White D. Tax Reform in Open Economies. Cheltenham, UK. 


\section{Annex}

\section{Annex: in Millions of USD}

\begin{tabular}{|c|c|c|c|c|c|c|c|c|c|c|}
\hline FDIs & 2006 & 2007 & 2008 & 2009 & 2010 & 2011 & 2012 & 2013 & 2014 & 2015 \\
\hline Austria & 4888 & 25492 & 7254 & 9397 & 2728 & 10820 & 4003 & 5813 & 4803 & 2790 \\
\hline Belgium & 58926 & 93448 & -13830 & 60966 & 43233 & 78329 & 6518 & 25188 & -8917 & 21281 \\
\hline Poland & 14576 & 19855 & 12279 & 10043 & 12800 & 15953 & 12441 & 3626 & 17612 & 13063 \\
\hline Slovakia & 5806 & 4018 & 4858 & -7 & 1770 & 2146 & 2826 & -604 & -332 & 803 \\
\hline $\begin{array}{l}\text { Czech } \\
\text { Republic } \\
\end{array}$ & 5465 & 10446 & 6449 & 2929 & 6147 & 2323 & 8000 & 3641 & 5492 & 1223 \\
\hline Hungary & 6817 & 3952 & 6314 & 1998 & 2195 & 6315 & 14427 & 3404 & 7557 & -15567 \\
\hline Estonia & 1335 & 2312 & 1826 & 1840 & 1509 & 1006 & 1566 & 750 & 604 & 130 \\
\hline Finland & 7655 & 12452 & -1124 & 718 & 7359 & 2552 & 4156 & -169 & 17303 & $\overline{1413}$ \\
\hline France & 25340 & 63511 & 37521 & 30735 & 13891 & 31671 & 16069 & 34264 & 239 & 39603 \\
\hline Germany & 55686 & 80227 & 8114 & 23807 & 65646 & 67573 & 28190 & 10479 & -6866 & 13327 \\
\hline Greece & 5358 & 2112 & 4490 & 2437 & 330 & 1144 & 1741 & 2817 & 2683 & 1140 \\
\hline Latvia & 1666 & 2324 & 1260 & 94 & 379 & 1454 & 1111 & 904 & 783 & 666 \\
\hline Ireland & -5545 & 24712 & -16421 & 25717 & 42807 & 23566 & 46940 & 46616 & 37417 & 188361 \\
\hline Italy & 39259 & 40209 & -10814 & 20078 & 9179 & 34355 & 93 & 24267 & 23224 & 19334 \\
\hline UK & 147396 & 176864 & 91798 & 89796 & 58180 & 42196 & 55626 & 51673 & 44845 & 38382 \\
\hline USA & 243151 & 221165 & 310092 & 150442 & 205850 & 236068 & 204134 & 206120 & 176217 & 353283 \\
\hline $\begin{array}{l}\text { Total } \\
\text { World 1,3 }\end{array}$ & 1446273 & 1990381 & 1571933 & 1177365 & 1500188 & 1693461 & 1484081 & 1563387 & 1437090 & 1824424 \\
\hline EU 1 & 526498 & 827563 & 317215 & 378303 & 380423 & 414981 & 294990 & 330015 & 253045 & 476877 \\
\hline OECD 1 & 956271 & 131656 & 846357 & 673420 & 715738 & 873970 & 724529 & 776736 & 628091 & 1016966 \\
\hline Brazil & 18822 & 34585 & 45058 & 25949 & 83749 & 96152 & 76098 & 53060 & 73086 & 64648 \\
\hline $\begin{array}{l}\text { China } \\
\end{array}$ & 956271 & 1318656 & 846357 & 673420 & 715738 & 873970 & 724529 & 776736 & 628091 & 1016966 \\
\hline India 2 & 18822 & 34585 & 45058 & 25949 & 83749 & 96152 & 76098 & 53060 & 73086 & 64648 \\
\hline Indonesia & 124082 & 156249 & 171535 & 131057 & 243703 & 280072 & 241214 & 290928 & 268097 & 249859 \\
\hline Russia & 20029 & 25228 & 43406 & 35581 & 27397 & 36499 & 23996 & 28153 & 33870 & 43858 \\
\hline $\begin{array}{l}\text { Saudi } \\
\text { Arabia } 2\end{array}$ & 4914 & 6929 & 9318 & 4878 & 13771 & 19241 & 19138 & 18817 & 21811 & 16917 \\
\hline $\begin{array}{l}\text { South } \\
\text { Africa 2 } \\
\end{array}$ & 37442 & 54922 & 75856 & 27752 & 31668 & 36868 & 30188 & 53397 & 29152 & 12423 \\
\hline
\end{tabular}

Source: Adapted from (OECD, 2017)

Darina Saxunova, Daniela Novackova and Jana Kajanova (2018), Journal of Eastern Europe Research in Business and Economics, DOI: 10.5171/2018.145385 